\title{
Electrochemical Degradation of the Dye Reactive Orange 16 using Electrochemical Flow-Cell
}

\author{
Luciano Gomes, ${ }^{a}$ Douglas W. Miwa, ${ }^{a}$ Geoffroy R. P. Malpass ${ }^{b}$ and Artur J. Motheo $*, a$ \\ ${ }^{a}$ Instituto de Química de São Carlos, Universidade de São Paulo, CP 780, \\ 13560-970 São Carlos-SP, Brazil \\ ${ }^{b}$ Centro de Ciências Naturais e Humanas (CCNH), Universidade Federal do ABC, \\ 09210-170 Santo André-SP, Brazil
}

\begin{abstract}
As remoções eletroquímicas de cor e do conteúdo orgânico de soluções do corante laranja reativo 16 (RO16) foram efetuadas usando uma célula em fluxo e um eletrodo de trabalho de Pt. As influências das variáveis do sistema, tais como fluxo, concentração de $\mathrm{NaCl}$, potencial aplicado e pH da solução, foram estudadas. A melhor remoção de cor foi de $93 \%(\lambda=493 \mathrm{~nm})$ após 60 min de eletrólise potentiostática a 2,2 V vs. ERH, usando $1,00 \mathrm{~g} \mathrm{~L}^{-1} \mathrm{NaCl}$ como eletrólito suporte. Os aumentos na concentração de $\mathrm{NaCl}$ e do potencial aumentam a velocidade de remoção de cor. A melhor remoção de carbono orgânico total (57\%) foi obtida com a aplicação de 1,8 V, sem membrana de separação, indicando que as melhores condições para remoção de cor não são necessariamente as melhores para remover conteúdo orgânico. A eficiência de degradação diminui com a diminuição do $\mathrm{pH}$ da solução.
\end{abstract}

Electrochemical removals of color and organic load from solutions containing the dye reactive orange 16 (RO16) were performed in an electrochemical flow-cell, using a platinum working electrode. The influence of the process variables flow-rate, such as $\mathrm{NaCl}$ concentration, applied potential and solution $\mathrm{pH}$, were studied. The best color removal achieved was $93 \%(\lambda=493 \mathrm{~nm})$ after $60 \mathrm{~min}$ at $2.2 \mathrm{~V} v s$. RHE electrolysis, using $1.00 \mathrm{~g} \mathrm{~L}^{-1} \mathrm{NaCl}$ as supporting electrolyte. The rises in the concentration of $\mathrm{NaCl}$ and applied potential increased the color removal rate. The best total organic carbon removal (57\%) was obtained at $1.8 \mathrm{~V}$, without the separating membrane, indicating that the ideal conditions for the color removal are not necessarily the same as those to remove the total organic carbon. The degradation efficiency decreased with the solution $\mathrm{pH}$ decrease.

Keywords: decolorization, textile effluent, electrochemical degradation, reactive dye, Pt electrode

\section{Introduction}

When untreated textile effluents are discharged into receiving water bodies many environmental problems can occur. The principal problems are that the presence of dyes (even at concentrations of $<1 \mathrm{ppm}$ ) that can cause considerable coloration in water courses, affect transparency to natural light (reducing photosynthesis), reduce gas solubility and may also present carcinogenic and mutagenic properties. ${ }^{1,2}$

Wide varieties of dyes are used in the textile industry and can be classified according to the manner in which

*e-mail: artur@iqsc.usp.br they are fixed to the textile fiber (e.g., direct, reactive) or by their chemical structure (e.g., azo, anthraquinone). In the textile industry, reactive dyes are widely used due to their relatively easy application in the dyeing process and stability during wear. As a result of this stability, reactive dyes may require more complicated systems to achieve their removal from effluent flows. A number of methods presented in the literature are traditionally used to treat textile effluent and they are generally based on physical, chemical and biological treatments. ${ }^{3-5}$ Physical treatment methods tend to simply transfer the pollutant to a different phase and biological methods can be prolonged and are not always efficient in removing color. Chemical methods are interesting as they are often capable of removing color and can include such techniques as oxidation by ozone, ${ }^{6}$ 
UV radiation, ${ }^{7}$ hydrogen peroxide, ${ }^{8}$ hypochlorite, ${ }^{9}$ Fenton's reagen $t^{10}$ and activated sludge ${ }^{11}$ amongst others.

Recently, there has been growing interest in the use of electrochemical techniques in the treatment of pollutants ${ }^{12}$ including textile dyes..$^{13}$ Compared to the methods presented above, electrochemical degradation processes present attractive advantages. These include the possibility that oxidizing agents (e.g., hydroxyl radicals, active chlorine) are electrochemically produced at the anode without the need, in many cases, to add further reagents. ${ }^{14,15}$ Additionally, the unselective nature of the produced oxidizing agents makes the method applicable for a large range of pollutants.

In order to the electrochemical reaction occur at an acceptable rate, sometimes it is necessary to add salts, such as $\mathrm{NaCl}$ and $\mathrm{Na}_{2} \mathrm{SO}_{4}$ (so-called supporting electrolytes), to the reaction mixture to increase conductivity. In the case of $\mathrm{NaCl}$, the presence of $\mathrm{Cl}^{-}$in addition to increasing conductivity also permits the electrochemical formation of free chlorine species, which can enhance the rate of pollutant removal. ${ }^{16}$ In addition, the physical space required for an electrochemical system is less than that from other methods and in some cases, considering the pollutant, it can be used in tandem with traditional biological treatment processes or even replacing them. ${ }^{17}$ Another advantage of the electrochemical process is that membranes can be used to separate the anodic and cathodic compartments of the electrochemical cell, enhancing the flow of ions toward the electrodes, but restricting the reverse flow minimizing the possibility of intermediate chemical reactions taking place.

The aim of the present paper is to study the electrochemical color removal of the azo dye reactive orange 16 (RO16) that has two sulfonate groups with negative charges in aqueous solution Figure 1.18,19<smiles>CC(=O)Nc1ccc2cc(S(=O)(=O)O[Na])c(N=Nc3ccc(S(=O)(=O)CCOS(=O)(=O)O[Na])cc3)c(O)c2c1</smiles>

Figure 1. Molecular structure of reactive orange 16 (RO16), which has the molecular formula $\mathrm{C}_{20} \mathrm{H}_{17} \mathrm{~N}_{3} \mathrm{O}_{11} \mathrm{~S}_{32} \mathrm{Na}$ and molecular weight of 617.53 .

This dye has attractive dying properties, especially for silk and cotton materials. However, it is highly resistant to conventional waste treatment methods. ${ }^{18,20}$ The present study was performed in an electrochemical flow-cell, using as the working electrode pure platinum $(\mathrm{Pt})$ plate. The influence of variables such as flow-rate, $\mathrm{NaCl}$ concentration, applied potential, membrane separation and $\mathrm{pH}$ were studied.

\section{Experimental}

\section{Electrochemical reactor}

The color removal assays were performed in an electrochemical flow-cell, using the experimental set up illustrated in Figure 2 and previously described in the literature. ${ }^{21,22}$ The working electrode (WE) was a Pt plate, (geometric area of $2 \mathrm{~cm}^{2}$ ) exposed to the solution. A stainless steel plate of the same area was used as the counter electrode (CE). All potentials are referred to the reversible hydrogen electrode (RHE). An IONAC membrane ${ }^{23}$ (opened in the center) was introduced through the cell, to promote the electrical contact between the electrolyte solution and the reference electrode, ${ }^{21}$ but did not separate the electrodes. This membrane was immersed in a solution of $0.5 \mathrm{~mol} \mathrm{~L}^{-1} \mathrm{H}_{2} \mathrm{SO}_{4}$ in which the reference electrode was placed. The distance between the $\mathrm{CE}$ and

(A)

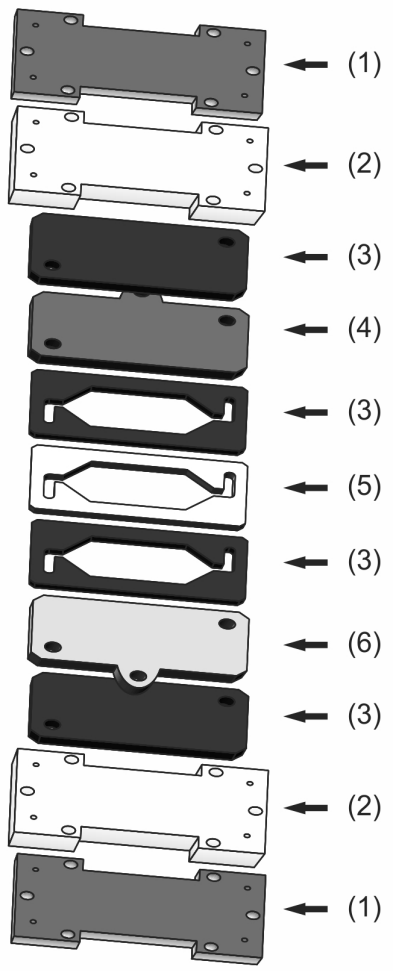

(B)

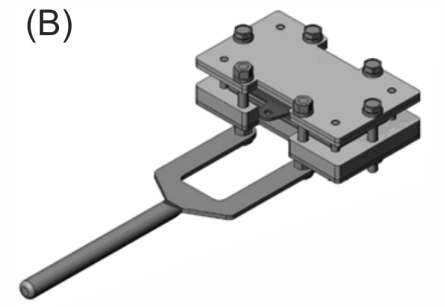

Figure 2. Electrochemical flow cell: (A) expanded view where (1) stainless steel support, (2) Teflon ${ }^{\circledast}$ support, (3) Viton ${ }^{\circledast}$ insulator, (4) anode, (5) Teflon ${ }^{\circledast}$ spacer and (6) cathode and (B) electrochemical cell stack. 
WE was controlled using Viton ${ }^{\circledR}$ and Teflon ${ }^{\circledR}$ spacers. The electrolyte flow through the cell was $1.24 \mathrm{~L} \mathrm{~h}^{-1}$ and the dye solution was pumped from the electrolyte reservoir through the cell using a peristaltic pump.

\section{Electrochemical characterization}

The voltammetric profiles of the electrodes were investigated to characterize the electrochemical processes that occur at the electrode/surface interface. Solutions of $\mathrm{RO} 16$ (35 $\left.\mathrm{mg} \mathrm{L}^{-1}\right)$ were prepared by dissolving the dye in aqueous solutions of $0.5 \mathrm{~mol} \mathrm{~L}^{-1} \mathrm{H}_{2} \mathrm{SO}_{4}$ and 0.25 to $1.00 \mathrm{~g} \mathrm{~L}^{-1}$ $\mathrm{NaCl}$. Electrolyses were performed in solutions of $50 \mathrm{~cm}^{3}$ and at two potentials, 1.8 and $2.2 \mathrm{~V}$, and electrolyte samples were collected at different times during electrolysis $(0,15,30,45$ and $60 \mathrm{~min})$. All measurements were performed at $25 \pm 2{ }^{\circ} \mathrm{C}$.

\section{UV-Vis spectroscopy}

The extent of color removal was determined using UV-Vis spectroscopy (path length $1 \mathrm{~cm}$, apparatus: Shimadzu Multispec 1501) by monitoring the band corresponding to the RO16 chromophore $(\lambda=493 \mathrm{~nm})$. Total organic carbon (TOC) was monitored using a TOC analyzer (TOC- $\mathrm{V}_{\mathrm{CPH}}$, Shimadzu). Profiles of these parameters were obtained by sampling solutions at predetermined time intervals during the degradation process.

\section{Results and Discussion}

Initially, the dye RO16 sample was characterized by UV-Visible spectroscopy (UV-Vis), as this technique can be applied to conjugated systems, where the molecular absorption in the ultraviolet and visible regions is dependent on the molecular electronic structure. ${ }^{24}$ Figure 3 presents the UV-Vis spectrum of the dye RO16.

The dye presents four characteristic bands, which agree with values found in the literature. ${ }^{25,26}$ The band at $254 \mathrm{~nm}$ is indicative of aromatic rings. ${ }^{27} \mathrm{~A}$ second band at $295 \mathrm{~nm}$

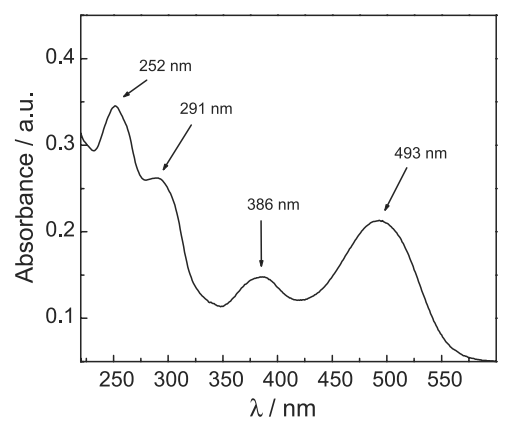

Figure 3. UV-Vis spectrum of RO16, as received, obtained between 220 and $600 \mathrm{~nm}$. can be attributed to the structure of gamma acetylated acid, ${ }^{27}$ that is a precursor for the synthesis of RO16. The band $386 \mathrm{~nm}$ is probably related to the azo group. Finally, the band at $493 \mathrm{~nm}$ due to the chromophore ${ }^{7,27}$ is observed and used to monitor the removal of color.

\section{Cyclic voltammetry experiments}

In order to understand the system from an electrochemical point of view, initial cyclic voltammetry (CV) experiments were performed. $\mathrm{CV}$ is a useful technique for probing the processes that occur at the electrode/solution interface..$^{28}$ The measurement of the current that result as the potential is varied can provide valuable insight into the reactions that occur at the electrode surface. As mentioned in the experimental section, the material chosen as the working electrode for this study was platinum (Pt) as it represents a well characterized electrochemical system, which can be used as a comparison. Figure 4(A) presents the voltammetric profiles of the Pt electrode in $\mathrm{H}_{2} \mathrm{SO}_{4}\left(0.5 \mathrm{~mol} \mathrm{~L}^{-1}\right)$.

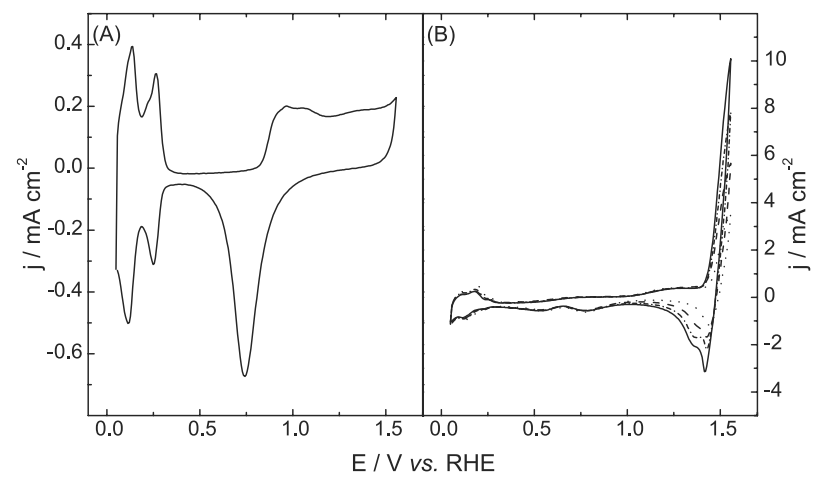

Figure 4. (A) Voltammetric profile of $\mathrm{Pt}$ in solution of $0.5 \mathrm{~mol} \mathrm{~L}^{-1} \mathrm{H}_{2} \mathrm{SO}_{4}$ and (B) adding different $\mathrm{NaCl}$ concentrations: (---) 0.25 ; (…) 0.50 ; (----) 0.75 and (-) $1.00 \mathrm{~g} \mathrm{~L}^{-1}, \nu=100 \mathrm{mV} \mathrm{s}^{-1}$.

In the presence of $\mathrm{H}_{2} \mathrm{SO}_{4}\left(0.5 \mathrm{~mol} \mathrm{~L}^{-1}\right)$ it can be seen that the voltammetric profile is comparable to the profile of Pt widely presented in the literature. ${ }^{29-31}$ The hydrogen adsorption and desorption occurs between 0.05 and $0.4 \mathrm{~V}$, the double layer area between 0.4 and $0.8 \mathrm{~V}$, formation of $\mathrm{PtO}_{x}$, between 0.8 and $1.55 \mathrm{~V}$ and reduction 1.55 and $0.4 \mathrm{~V}$ on the reverse sweep, respectively. ${ }^{29-31}$

When $\mathrm{NaCl}$ is added to the electrolyte (see Figure 4(B)) a distinct modification of the CV profile occurs. This is manifested by the suppression of the formation of $\mathrm{PtO}_{\mathrm{x}}$, $\mathrm{PtO}_{x}$ reduction and $\mathrm{H}$-adsorption/desorption, probably due to the specific adsorption of $\mathrm{Cl}^{-}$ions at the $\mathrm{Pt}$ surface. ${ }^{32} \mathrm{In}$ the presence of $\mathrm{NaCl}$ it is possible to observe an anodic process, which corresponds to the onset of $\mathrm{Cl}_{2}$ formation and the cathodic reduction of adsorbed chloride species, on the reverse sweep. ${ }^{33}$ 
When the potential limits are extended to $1.8 \mathrm{~V}$ (Figure 5), in the presence of $\mathrm{H}_{2} \mathrm{SO}_{4}\left(0.5 \mathrm{~mol} \mathrm{~L}^{-1}\right)$ no additional redox processes are observed up to approximately $1.6 \mathrm{~V}$, where the oxygen evolution reaction commences. With the addition of $\mathrm{NaCl}$, a distinct redox process can be observed at $c a .1 .65 \mathrm{~V}$ (positive sweep) with an associated reduction peak (reverse sweep) at $1.37 \mathrm{~V}$, attributable to the oxidation of $\mathrm{Cl}^{-}$to form $\mathrm{Cl}_{2}($ ca. $1.65 \mathrm{~V})$ and the subsequent reduction of $\mathrm{Cl}_{2}$ on the reverse sweep $(1.37 \mathrm{~V})$. After this process, competition between the oxygen evolution and chlorine evolution occurs. When RO16 (solid line) is added, minimal variation in the voltammetric profile is observed, indicating that oxidation, if it occurs, takes place principally by the indirect action of species in solution, generated electrochemically at the electrode surface.

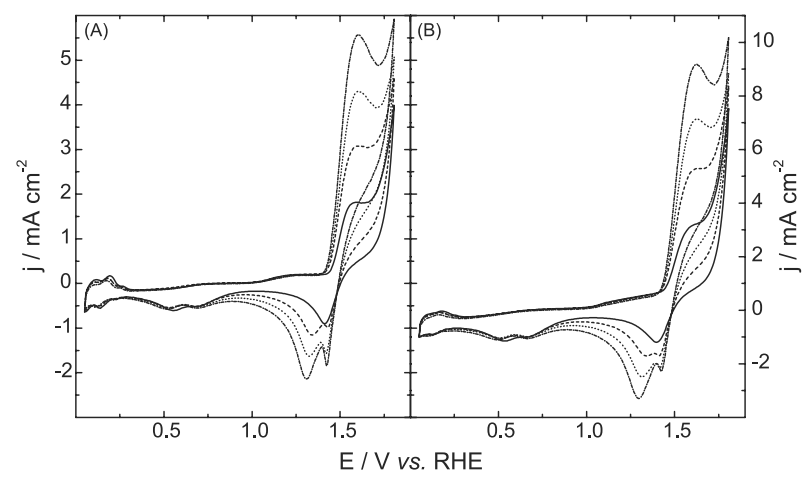

Figure 5. (A) Voltammetric profile of $\mathrm{Pt}$ in $0.5 \mathrm{~mol} \mathrm{~L}^{-1} \mathrm{H}_{2} \mathrm{SO}_{4}$ solution with different concentrations of $\mathrm{NaCl}$ : (---) $0.25,(\cdots)$.0.50 , (--.--) 0.75 and (-) $1.00 \mathrm{~g} \mathrm{~L}^{-1}$ and (B) under the same conditions with addition of $35 \mathrm{mg} \mathrm{L}^{-1}$ of dye RO16, $v=100 \mathrm{mV} \mathrm{s}^{-1}$.

\section{Electrolysis}

As stated in the previous section, an anodic process was observed in the voltammogram at a potential of $c a .1 .3 \mathrm{~V}$. In order to investigate if it is possible to degrade the RO16 at this potential, constant potential (potentiostatic) electrolysis was performed in $\mathrm{H}_{2} \mathrm{SO}_{4}(0.5 \mathrm{~mol} \mathrm{~L}-1)$. This would be interesting as it would enable "selective" degradation of the dye at low potentials. However, it was observed that a maximum of only $7.8 \%$ of color was removed after $1 \mathrm{~h}$ of electrolysis and that corresponding TOC removal was insignificant. Similar results were obtained in the presence of $\mathrm{NaCl}$. This indicates that higher potentials (energy) that enter the region of $\mathrm{O}_{2}$ and $\mathrm{Cl}_{2}$ evolution are in fact required to break down the dye molecule. In this light, it was decided to apply potentials of 1.8 and $2.2 \mathrm{~V}$ during electrolysis, with variation of parameters as flow-rate, $\mathrm{NaCl}$ concentration and $\mathrm{pH}$.

\section{Effect of electrolyte flow-rate}

Firstly, it was decided to investigate the effect of flowrate. The flow-rate is extremely important as careful tuning of the electrolyte transfer rate to the electrode surface can result in an improvement in the degradation performance. It is also interesting from a practical point of view as it indicates if the reactions occurring are either controlled by mass-transfer or by electron transfer.

In the present study, the flow-rate was varied from 2.3 to $25 \mathrm{~cm}^{3} \mathrm{~min}^{-1}$ (Figure 6), using a fixed potential of $2.2 \mathrm{~V}$ and $1.00 \mathrm{~g} \mathrm{~L}^{-1} \mathrm{NaCl}$ in an undivided cell. This potential was chosen as it enters the region of extensive $\mathrm{O}_{2}$ and $\mathrm{Cl}_{2}$ evolution. It was observed that the rate of color removal increases proportionally with increasing flow-rate until a maximum of $c a .95 \%$ that is reached at $25 \mathrm{~cm}^{3} \mathrm{~min}^{-1}$ (inset Figure 6). Based on these results, the flow-rate used in all experiments was $25 \mathrm{~cm}^{3} \mathrm{~min}^{-1}$.

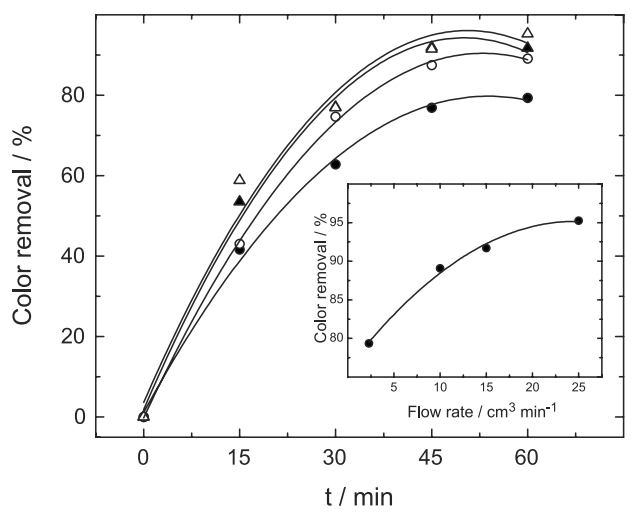

Figure 6. Flow-rate effects in the color removal using $(\bigcirc)$ 2.3, (○) 10, (ム) 15 and $(\triangle) 25 \mathrm{~cm}^{3} \mathrm{~min}^{-1}$, at $2.2 \mathrm{~V}$ and $1.00 \mathrm{~g} \mathrm{~L}^{-1} \mathrm{NaCl}$.

\section{Influence of $\mathrm{NaCl}$ concentration and applied potential}

Previous studies ${ }^{21,34}$ investigated the effect of varying the $\mathrm{NaCl}$ concentration $\left(0.25-1.00 \mathrm{~g} \mathrm{~L}^{-1}\right)$ and have shown that the $\mathrm{NaCl}$ concentration strongly influences the rate of color and organic removal. In the present study, two different potentials were applied: 1.8 and $2.2 \mathrm{~V}$ in order to understand the effect of this variable on the rate of $\mathrm{Cl}_{2}$ production and subsequent dye removal. In an electrochemical process, the pollutants can be destroyed by direct or indirect oxidation process. ${ }^{12}$ In the direct process, the dye is adsorbed onto platinum electrode surface and is destroyed by direct electron transfer ${ }^{35}$ In the indirect process, the degradation occurs by the formation (at the electrode or in solution) of oxidizing species in situ, which then react with the organic species in solution. ${ }^{23}$ According to reactions 1-5 in the presence of $\mathrm{NaCl}$ both $\mathrm{Cl}_{2}$ and hypochlorite $\left(\mathrm{ClO}^{-}\right)$can be formed and subsequently result in the degradation of the dye in solution:21,34,36 
Anode: $\quad 2 \mathrm{Cl}^{-} \rightarrow \mathrm{Cl}_{2}+2 \mathrm{e}^{-}$

Cathode: $2 \mathrm{H}_{2} \mathrm{O}+2 \mathrm{e}^{-} \rightarrow \mathrm{H}_{2}+2 \mathrm{OH}^{-}$

Solution: $\mathrm{Cl}_{2}+2 \mathrm{OH}^{-} \rightarrow \mathrm{H}_{2} \mathrm{O}+\mathrm{ClO}^{-}+\mathrm{Cl}^{-}$

$\mathrm{HOCl} \rightarrow \mathrm{H}^{+}+\mathrm{OCl}^{-}$

Dye $+\mathrm{OCl}^{-} \rightarrow$ intermediates $\rightarrow \mathrm{CO}_{2}+\mathrm{Cl}^{-}+\mathrm{H}_{2} \mathrm{O}$

Additionally, as discussed by previous authors, ${ }^{37,38}$ there is also the possibility that intermediates of oxygen evolution form oxychloro species that can mediate organic destruction (reactions 6 and 7):

$\mathrm{MO}_{x}(\mathrm{OH})+\mathrm{Cl}^{-} \rightarrow \mathrm{MO}_{x}(\mathrm{HOCl})+\mathrm{e}^{-}$

Dye $+\mathrm{MO}_{\mathrm{x}}(\mathrm{HOCl}) \rightarrow$ intermediates $\rightarrow \mathrm{MO}_{\mathrm{x}}+\mathrm{CO}_{2}+$

$\mathrm{Cl}^{-}+\mathrm{H}_{2} \mathrm{O}+\mathrm{H}^{+}$

Indeed, it is probable that both the degradation paths (1-5) and (6-7) play simultaneous roles in the removal of the dye. ${ }^{37,38}$ The role of $\mathrm{Cl}^{-}$in producing an anodic shift in (decreasing the activity towards) the oxygen evolution reaction may also be important.

The greater the concentration of $\mathrm{NaCl}$, greater is the formation rate of $\mathrm{Cl}_{2} / \mathrm{ClO}^{-}$. The effect of $\mathrm{NaCl}$ concentration on the level of color removal is presented in Figure 7. It can be seen that distinct behavior exists at the different potentials applied. At $1.8 \mathrm{~V}$, there is limited color removal at $\mathrm{NaCl}$ concentrations of $0.25,0.50$ and $0.75 \mathrm{~g} \mathrm{~L}^{-1}$ and significant levels (ca. 62\%) are only obtained at $1.00 \mathrm{~g} \mathrm{~L}^{-1}$. On the other hand, when the potential is increased to $2.2 \mathrm{~V}$ color removals up to $93 \%$ are obtained in less than $1 \mathrm{~h}$ of treatment.

Thus, in the absence of a separating membrane, it is observed that the best color removal was obtained using $1.00 \mathrm{~g} \mathrm{~L}^{-1} \mathrm{NaCl}$ at $2.2 \mathrm{~V}$, with $93 \%$ of color being removed. At $1.8 \mathrm{~V}$, the best removal was $61 \%$ using the same $\mathrm{NaCl}$ concentration. The color was removed obeying pseudo first order kinetics and the values of the rate-constants (k) obtained are presented in Table 1.

In any energy-intensive process, a measure of the energy consumption is of vital importance. According to IUPAC guidelines, the efficiency of an electrically driven oxidation process can be expressed according to the kinetic model

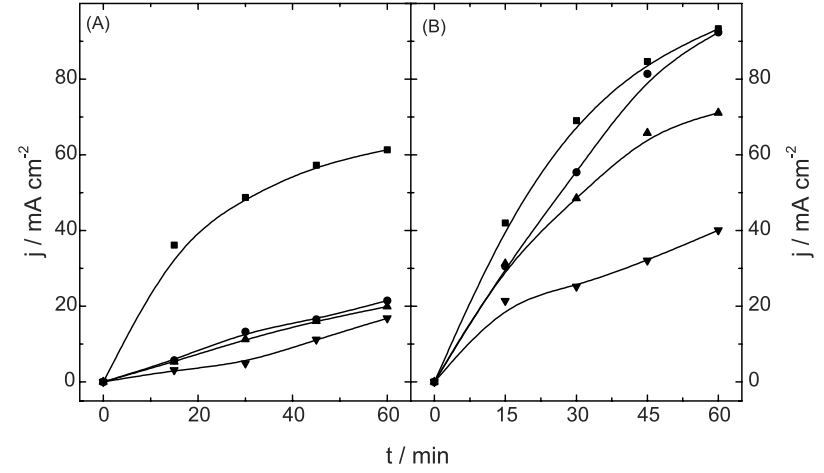

Figure 7. Effect of $\mathrm{NaCl}$ concentration on the color removal using potential of (A) 1.8 and (B) $2.2 \mathrm{~V}$ with $\mathrm{NaCl}$ concentrations of ( $\mathbf{\nabla}) 0.25$, (४) $0.50,(\bullet) 0.75$ and $(\boldsymbol{\square}) 1.00 \mathrm{~g} \mathrm{~L}^{-1}$, without membrane.

that corresponds to the system under investigation. ${ }^{39}$ In this study, as the color is removed obeying first order kinetics, the energy per order $\left(\mathrm{E}_{\mathrm{EO}}\right)$ can be applied as the appropriate figure of merit. ${ }^{39}$ The $\mathrm{E}_{\mathrm{EO}}\left(\mathrm{kWh} \mathrm{m}^{3}\right.$ order $\left.^{-1}\right)$ is defined as the electrical energy (in $\mathrm{kW} \mathrm{h}$ ) required to bring about the degradation of a contaminant $\mathrm{C}$ by one order of magnitude in $1 \mathrm{~m}^{3}$ of contaminated water or air and is given by the following equation: ${ }^{39}$

$E_{E O}=\frac{P t 1000}{V \log \left(C_{i} / C_{t}\right)}$

where $\mathrm{P}$ is the rated power $(\mathrm{kW}), \mathrm{t}$ the time $(\mathrm{h}), \mathrm{V}$ the treated volume ( $\mathrm{L}$ ) and $\mathrm{C}_{\mathrm{i}}$ and $\mathrm{C}_{\mathrm{t}}$ represent the initial concentration and the concentration after a given time, $t$, respectively. The results of $\mathrm{E}_{\mathrm{EO}}$ for electrochemical degradation of RO16 are presented in Table 1 for degradation in an undivided cell.

It is observed that with the increase of $\mathrm{NaCl}$ concentration, the operating cell potential is reduced and the energy consumption is lower, as described previously. ${ }^{21}$ However, the $\mathrm{E}_{\mathrm{EO}}$ values at $2.2 \mathrm{~V}$ are much greater than at $1.8 \mathrm{~V}$, due to the greater applied potential and competition between $\mathrm{O}_{2}$ and $\mathrm{Cl}_{2}$ formation at the higher potential. It should be noted that the $\mathrm{E}_{\mathrm{EO}}$ values presented in Table 1 are much lower than those previously obtained in this laboratory for real textile effluent, ${ }^{21,40}$ indicating the complex nature of the treatment required when change is made from simulated to real effluents.

Table 1. Values of first order rate constant $(\mathrm{k})$ and energy per order $\left(\mathrm{E}_{\mathrm{EO}}\right)$ at 1.8 and $2.2 \mathrm{~V}$ for an undivided cell

\begin{tabular}{|c|c|c|c|c|}
\hline \multirow{2}{*}{$\mathrm{NaCl} / \mathrm{g} \mathrm{L}^{-1}$} & \multicolumn{2}{|c|}{$1.8 \mathrm{~V}$} & \multicolumn{2}{|c|}{$2.2 \mathrm{~V}$} \\
\hline & $\mathrm{k} / \min ^{-1}$ & $\mathrm{E}_{\mathrm{EO}} / \mathrm{kW} \mathrm{h} \mathrm{m}^{-3}$ order $^{-1}$ & $\mathrm{k} / \min ^{-1}$ & $\mathrm{E}_{\mathrm{EO}} / \mathrm{kW} \mathrm{h} \mathrm{m}^{-3}$ order $^{-1}$ \\
\hline 0.25 & 0.00286 & 0.1444 & 0.00667 & 3.5973 \\
\hline 0.50 & 0.0038 & 0.1536 & 0.01242 & 2.1168 \\
\hline 0.75 & 0.00621 & 0.1053 & 0.01982 & 1.0031 \\
\hline 1.00 & 0.01415 & 0.0545 & 0.02432 & 0.903 \\
\hline
\end{tabular}


After establishing that up to $93 \%$ of color can be removed at $2.2 \mathrm{~V}$, it was decided to investigate the effect of separating the cell with a membrane. The objective of using the membrane to separate the flow-cell was to verify the influence in the formation of hypochlorite $\left(\mathrm{ClO}^{-}\right)$, which is formed after the reaction of anodically formed $\mathrm{Cl}_{2}$ and cathodically formed $\mathrm{HO}^{-}$(reactions 1-4). With cell separation, the formation of $\mathrm{OCl}^{-}$should decrease as the crossover of the species will be limited and this may affect the degradation process.

Figure 8 presents the extent of color removal using a separating membrane. Comparing with the obtained results without the membrane it can be seen that there is a decrease of $17.6 \%$ in the color removal at $1.8 \mathrm{~V}$ and $13 \%$ at $2.2 \mathrm{~V}$. Again, it is observed that the best color removal was obtained at $2.2 \mathrm{~V}$. These results indicate that the use of a membrane is capable of reducing the formation of $\mathrm{ClO}^{-}$as seen in previous papers..$^{41}$ The $\mathrm{E}_{\mathrm{EO}}$ values with and without the membrane are given in Figure 9.

Total organic carbon (TOC) is a very important parameter applied to wastewater pollution analyses. ${ }^{42}$ For

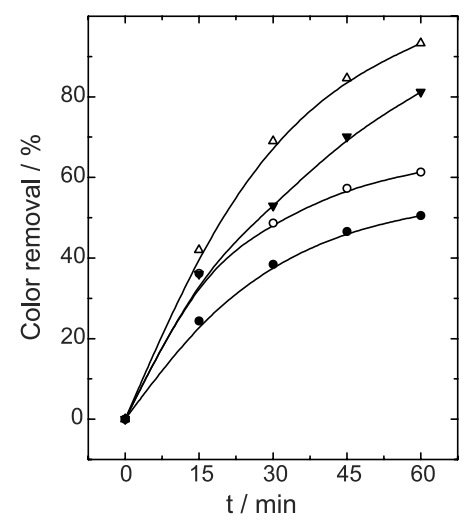

Figure 8. Color removal using $1.00 \mathrm{~g} \mathrm{~L}^{-1} \mathrm{NaCl}$ added to a $0.5 \mathrm{~mol} \mathrm{~L}^{-1}$ $\mathrm{H}_{2} \mathrm{SO}_{4}$ solution with $35 \mathrm{mg} \mathrm{L}^{-1} \mathrm{f} \mathrm{RO} 16$, at $1.8 \mathrm{~V}(\bullet)$ with and $(\mathrm{O})$ without membrane and second at $2.2 \mathrm{~V}(\boldsymbol{\nabla})$ with and $(\triangle)$ without membrane.

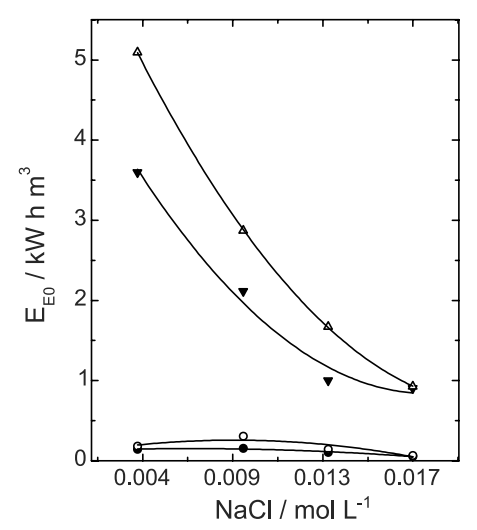

Figure 9. Energy per order of degradation of RO16 using different $\mathrm{NaCl}$ concentrations in $\mathrm{H}_{2} \mathrm{SO}_{4}$ medium $\left(0.5 \mathrm{~mol} \mathrm{~L}^{-1}\right)$ at $1.8 \mathrm{~V}(\bullet)$ without and (O) with membrane and at $2.2 \mathrm{~V}(\boldsymbol{\nabla})$ without and $(\triangle)$ with membrane. the degradation of RO16 TOC removal was analyzed as function of potential applied, $\mathrm{NaCl}$ concentrations and use of a membrane. The results are presented in Figure 10.

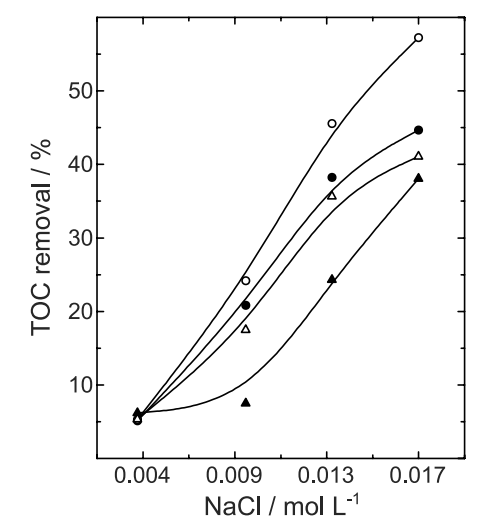

Figure 10. TOC removal using different $\mathrm{NaCl}$ concentrations in $0.5 \mathrm{~mol} \mathrm{~L}^{-1} \mathrm{H}_{2} \mathrm{SO}_{4}$ solution at $1.8 \mathrm{~V}(\bullet)$ with and $(\bigcirc)$ without membrane and at $2.2 \mathrm{~V}(\mathbf{\Delta})$ with and $(\triangle)$ without membrane.

It is observed that the best TOC removal (57\%) was obtained at the potential of $1.8 \mathrm{~V}$, without the separating membrane. If only the color removal is analyzed, the best parameter for RO16 degradation will be $2.2 \mathrm{~V}$ without the separating membrane. But with TOC results, it is clearly observed that when a greater potential is applied, the color removal is faster, however the total degradation of RO16 was reduced. It was also observed that at $1.8 \mathrm{~V}$, with and without membrane, the $\mathrm{E}_{\mathrm{EO}}$ was lower, compared to $2.2 \mathrm{~V}$.

According to other authors, ${ }^{37,38}$ the presence of $\mathrm{Cl}^{-}$in solution can shift the oxygen evolution (OER) reaction to more positive potentials, which basically can be interpreted as an inhibition of the process. Thus, at $1.8 \mathrm{~V}$, the degradation of the dye is probably due to the combination of reactions 1-7. On the other hand, at $2.2 \mathrm{~V}$ there is probably greater completion between the OER and dye removal through reactions 1-7.

\section{pH effect}

After studying the cell parameters (flow-rate, $\mathrm{NaCl}$ concentration, applied potential and cell separation), the influence of $\mathrm{pH}$ on the color removal, energy per order and kinetics was analyzed. From Figure 11, it can be observed that the color removal decreases as the $\mathrm{pH}$ decreases. The best color removal occurs at a $\mathrm{pH}$ of 1.6 , being approximately $94 \%$. However when the $\mathrm{pH}$ value was changed to $\mathrm{pH} 6.3$, the color removal decreased to $63 \%$. At $\mathrm{pH}>7$, color removal is lower, reaching only $27 \%$ at $\mathrm{pH} 12$. Consequently, the rate constants and energy per order are also observed to be less favorable at higher $\mathrm{pH}$ values. Table 2 gives the values of the rate-constants and $\mathrm{E}_{\mathrm{EO}}$ for different $\mathrm{pHs}$. 


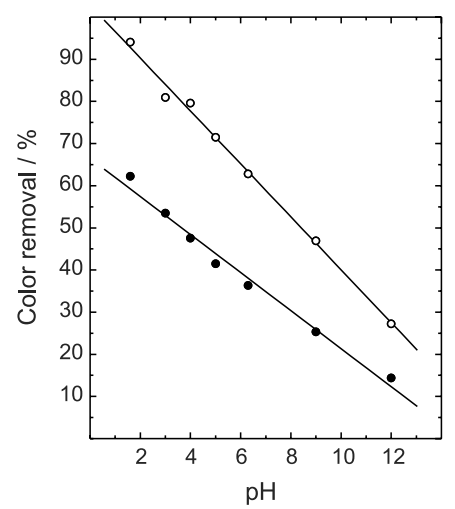

Figure 11. Color removal from a $1.00 \mathrm{~g} \mathrm{~L}^{-1} \mathrm{NaCl}$ solution as function of $\mathrm{pH}$ at $(\bigcirc) 1.8$ and (O) $2.2 \mathrm{~V}$ for an undivided cell.

Table 2. Values of first order rate constant (k) and energy per order $\left(\mathrm{E}_{\mathrm{EO}}\right)$ as a function of $\mathrm{pH}$

\begin{tabular}{lcc}
\hline $\mathrm{pH}$ & $\mathrm{k} / \mathrm{min}^{-1}$ & $\mathrm{E}_{\mathrm{EO}} / \mathrm{kW} \mathrm{h} \mathrm{m}^{-3}$ order $^{-1}$ \\
\hline 1.6 & 0.037 & 0.45 \\
2.9 & 0.032 & 0.47 \\
4.0 & 0.029 & 0.51 \\
5.0 & 0.022 & 0.56 \\
6.3 & 0.020 & 0.89 \\
9.0 & 0.013 & 1.56 \\
12.0 & 0.006 & 2.72 \\
\hline
\end{tabular}

It is observed that with the increase of $\mathrm{NaCl}$ concentration, the operating cell potential is reduced and the energy consumption is lower, as described in the work of Malpass et al. ${ }^{21}$ The $\mathrm{E}_{\mathrm{EO}}$ values at $2.2 \mathrm{~V}$ are much greater than at $1.8 \mathrm{~V}$, because it presents a higher degree of oxygen and chlorine evolution, which increase the current and consequently increase the $\mathrm{E}_{\mathrm{EO}}$ values.

In the present study the formation of organochlorine by-products was not performed. However, previous studies indicate that during electrochemical degradation such intermediates are also removed during the degradation process. ${ }^{43-45}$

\section{Conclusions}

The present study demonstrates that is possible to degrade a commercial dye using a Pt electrode. The addition of $\mathrm{NaCl}$ is very important due to the in situ formation of active chlorine species, which are strong oxidizing agents. The color removal is considered an important parameter in textile dye degradation, however in this work TOC results indicate that the best conditions for color removal are not the best for total degradation. It is our hope that this study can be used as a reference for future studies of new electrodes, comparing the parameters of efficiencies between electrodes of different metals, such as $\mathrm{DSA}^{\oplus},{ }^{45}$ boron-doped diamond (BDD), amongst others.

\section{Acknowledgements}

The authors gratefully acknowledge the financial support from FAPESP (Fundação de Amparo à Pesquisa do Estado de São Paulo) and CNPq (Conselho Nacional de Desenvolvimento Científico e Tecnológico), Brazil.

\section{References}

1. Carneiro, P. A.; Osugi, M. E.; Fugivara, C. S.; Boralle, N.; Furlan, M.; Zanoni, M. V. B.; Chemosphere 2005, 59, 431.

2. Meric, S.; Kaptan, D.; Olmez, T.; Chemosphere 2004, 54, 435.

3. Isik, M.; Enzyme Microb. Technol. 2004, 35, 399.

4. Libra, J. A.; Borchert, M.; Vigelahn, L.; Storm, T.; Chemosphere 2004, 56, 167.

5. Ong, S. A.; Toorisaka, E.; Hirata, M.; Hano, T.; Sep. Purif. Technol. 2005, 42, 297.

6. Gutowska, A.; Kaluzna-Czaplinska, J.; Jozwiak, W. K.; Dyes Pigm. 2007, 74, 41.

7. Bilgi, S.; Demir, C.; Dyes Pigm. 2005, 66, 69.

8. Baldrian, P.; Merhautova, V.; Gabriel, J.; Nerud, F.; Stopka, P.; Hruby, M.; Benes, M. J.; Appl. Catal., B 2006, 66, 258.

9. Bredereck, K.; Schumacher, C.; Dyes Pigm. 1993, 21, 45.

10. Kusic, H.; Koprivanac, N.; Srsan, L.; J. Photochem. Photobiol., A 2006, 181, 195.

11. Arslan-Alaton, W.; Eremektar, G.; Babuna, F. G.; Selcuk, H.; Orhon, D.; Fresenius Environ. Bull. 2004, 13, 1040.

12. Martinez-Huitle, C. A.; Ferro, S.; Chem. Soc. Rev. 2006, 35, 1324.

13. Martínez-Huitle, C. A.; Brillas, E.; Appl. Catal., B 2009, 87, 105.

14. Troster, I.; Fryda, M.; Herrmann, D.; Schafer, L.; Hanni, W.; Perret, A.; Blaschke, M.; Kraft, A.; Stadelmann, M.; Diamond Relat. Mater. 2002, 11, 640.

15. Kraft, A.; Stadelmann, M.; Blaschke, M.; J. Hazard. Mater. 2003, 103, 247.

16. Chen, G. H.; Sep. Purif. Technol. 2004, 38, 11.

17. Juttner, K.; Galla, U.; Schmieder, H.; Electrochim. Acta 2000, 45, 2575.

18. Andrade, L. S.; Tasso, T. T.; da Silva, D. L.; Rocha-Filho, R. C.; Bocchi, N.; Biaggio, S. R.; Electrochim. Acta 2009, 54, 2024.

19. Won, S. W.; Choi, S. B.; Yun, Y. S.; Biochem. Eng. J. 2006, 28, 208.

20. Carneiro, P. A.; Osugi, M. E.; Sene, J. J.; Anderson, M. A.; Zanoni, M. V. B.; Electrochim. Acta 2004, 49, 3807.

21. Malpass, G. R. P.; Miwa, D. W.; Mortari, D. A.; Machado, S. A. S.; Motheo, A. J.; Water Res. 2007, 41, 2969. 
22. Malpass, G. R. P.; Motheo, A. J.; J. Appl. Electrochem. 2001, $31,1351$.

23. Motheo, A. J.; Gonzalez, E. R.; Tremiliosi, G.; Olivi, P.; de Andrade, A. R.; Kokoh, B.; Leger, J. M.; Belgsir, E. M.; Lamy, C.; J. Braz. Chem. Soc. 2000, 11, 16.

24. Silverstein, R. M.; Bassler, G. C.; Morril, T. C.; Spectrometric Identification of Organic Compounds, John Wiley \& Sons: New York, 1991.

25. Catanho, M.; Malpass, G. R. P.; Motheo, A. J.; Appl. Catal., B 2006, 62, 193.

26. Gomes, L.; Freitas, R. G.; Malpass, G. R. P.; Pereira, E. C.; J. Appl. Electrochem. 2009, 39, 117.

27. Catanho, M.; Malpass, G. R. P.; Motheo, A. J.; Quim. Nova. 2006, 29, 983.

28. Mabbott, G. A.; J. Chem. Educ. 1983, 60, 697.

29. Jerkiewicz, G.; Vatankhah, G.; Lessard, J.; Soriaga, M. P.; Park, Y. S.; Electrochim. Acta 2004, 49, 1451.

30. Bard, A. J.; Faulkner, L. R.; Electrochemical Methods: Fundamentals and Applications, $2^{\text {nd }}$ ed.; John Wiley \& Sons, Inc.: New York, 2001.

31. Conway, B. E.; Prog. Surf. Sci. 1995, 49, 331.

32. Arikado, T.; Iwakura, C.; Tamura, H.; Electrochim. Acta 1977, 22, 229.

33. Kodera, F.; Umeda, M.; Yamada, A.; Anal. Chim. Acta 2005, 537, 293.

34. Miwa, D. W.; Malpass, G. R. P.; Machado, S. A. S.; Motheo, A. J.; Water Res. 2006, 40, 3281.

35. Rajkumar, D.; Palanivelu, K.; J. Hazard. Mater. 2004, 113, 123.
36. Mohan, N.; Balasubramanian, N.; Subramanian, V.; Chem. Eng. Technol. 2001, 24, 749.

37. Martinez-Huitle, C. A.; Ferro, S.; De Battisti, A.; Electrochem. Solid-State Lett. 2005, 8, D35.

38. Scialdone, O.; Randazzo, S.; Galia, A.; Silvestri, G.; Water Res. 2009, 43, 2260.

39. Bolton, J. R.; Bircher, K. G.; Tumas, W.; Tolman, C. A.; Pure Appl. Chem. 2001, 73, 627.

40. Malpass, G. R. P.; Miwa, D. W.; Machado, S. A. S.; Motheo, A. J.; J. Hazard. Mater. 2008, 156, 170.

41. Barbosa, C. P.; Malpass, G. R. P.; Miwa, D. W.; Gomes, L.; Bertazzoli, R.; Motheo, A. J.; J. Braz. Chem. Soc. 2010, 21, 651.

42. Thomas, O.; El Khorassani, H.; Touraud, E.; Bitar, H.; Talanta 1999, 50, 743.

43. Rajkumar, D.; Kim, J. G.; Palanivelu, K.; Chem. Eng. Technol. 2005, 28, 98 .

44. Kokoh, K. B.; Hahn, F.; Belgsir, E. M.; Lamy, C.; de Andrade, A. R.; Olivi, P.; Motheo, A. J.; Tremiliosi-Filho, G.; Electrochim. Acta 2004, 49, 2077.

45. Malpass, G. R. P.; Neves, R. S.; Motheo, A. J.; Electrochim. Acta 2006, 52, 936.

Submitted: December 15, 2010

Published online: March 15, 2011

FAPESP has sponsored the publication of this article. 